\title{
Precedents Construing Statutes Administered by Federal Agencies After the Chevron Decision: What Gives?
}

\author{
Jahan Sharifi $\dagger$
}

The scope and power of administrative agencies has expanded dramatically in the United States over the last forty years; not only has government become significantly larger, "but the welfare state [has] increasingly decid[ed] questions previously left to the individual or otherwise unregulated." The statutes administered by these agencies have increased in number and the effects of federal regulation invade nearly every aspect of modern life. Because of this expansion of the power of federal government, "[a]n important function of the modern judiciary is to ensure that decisions by administrative agencies remain within statutory boundaries."

However, it is not immediately evident how to allocate the responsibility for interpreting statutes administered by agencies. Both the courts and administrative agencies can make powerful arguments that they should have the authority to interpret statutes that govern the agencies. On the one hand, "[t]o determine "what the law is' in the context of an actual controversy that turns on a question of statutory meaning is the quintessential judicial function." 3 The roots of this argument reach back to Marbury $v$ Madison and to Hamilton's statement in Federalist 78 that "[ $t]$ he interpretation of the laws is the proper and peculiar province of the courts. ... It must therefore belong to them to ascertain ...

$\dagger$ B.A. 1987, The University of Chicago; M.G.A. 1991, The University of Pennsylvania; J.D. Candidate 1993, The University of Chicago.

1 Ernest Gellhorn, Opening Remarks: Administrative Law in Transition, 38 Admin L Rev 107, 110 (1986).

2 Kenneth W. Starr, Judicial Review in the Post-Chevron Era, 3 Yale J Reg 283 (1986).

${ }^{3}$ Cynthia R. Farina, Statutory Interpretation and the Balance of Power in the Administrative State, 89 Colum L Rev 452 (1989). See also Cass R. Sunstein, Law and Administration after Chevron, 90 Colum L Rev 2071, 2085 (1990) ("Before the discretionary, policy-making administrative agency became pervasive, the notion that courts would interpret the law, including federal statutes, seemed axiomatic.").

45 US (1 Cranch) 137, 177 (1803) ("It is emphatically the province and duty of the judicial department to say what the law is."). 
the meaning of any particular act proceeding from the legislative body."

On the other hand, administrative agencies might be better prepared to interpret statutes that they work with every day. ${ }^{6}$ The agencies' technical expertise and familiarity with the history, purpose and current congressional views of their governing statutes make them better able to judge what will best effectuate the purposes of the legislation that they are charged with administering. ${ }^{7}$ Perhaps the strongest argument for giving administrative agencies the authority to interpret their governing statutes is that agencies, unlike courts, are accountable to the electorate, albeit indirectly. ${ }^{8}$

For many years, the question of whether the courts should independently interpret statutes governing administrative agencies or defer to the agencies' interpretations remained unsettled. ${ }^{9}$ Some

- Federalist 78 (Hamilton) in Max Beloff, ed, The Federalist 398 (Basil Blackwell, 2d ed 1987).

- Farina, 89 Colum L Rev at 453 (cited in note 3); Sunstein, 90 Colum L Rev at 2086-87 (cited in note 3 ).

7 See, for example, Antonin Scalia, Judicial Deference to Administrative Interpretations of Law, 1989 Duke L J 511, 514; Stephen G. Breyer, Judicial Review of Questions of Law and Policy, 38 Admin L Rev 363, 368 (1986).

Sunstein, 90 Colum L Rev at 2087 (cited in note 3).

- Judge Friendly wrote in 1976:

We think it is time to recognize ... that there are two lines of Supreme Court decisions on this subject which are analytically in conflict, with the result that a court of appeals must choose the one it deems more appropriate for the case at hand. Leading cases support [ ] the view that great deference must be given to the decisions of an administrative agency applying a statute to the facts and that such decisions can be reversed only if without rational basis .... However, there is an impressive body of law sanctioning free substitution of judicial for administrative judgment when the question involves the meaning of a statutory term.

Pittston Stevedoring Corp. v Dellaventura, 544 F2d 35, 49 (2d Cir 1976) (citations omitted), aff'd as Northeast Marine Terminal Co., Inc. v Caputo, 432 US 249 (1977). See Thomas W. Merrill, Judicial Deference to Executive Precedent, 101 Yale L J 969, 971-75 (1992); Breyer, 38 Admin L Rev at 366-67 (cited in note 7). 
cases argued for great deference; ${ }^{10}$ other cases upheld a court's power to interpret a statute as it saw fit. ${ }^{11}$

In Chevron $v$ Natural Resources Defense Council Inc., ${ }^{12}$ a unanimous Supreme Court adopted a clear two-step approach for deciding when to accept an agency's interpretation of a statute. The first step requires that a court determine whether there is clear congressional intent that governs the interpretation of the statute. If Congress has spoken to the issue, the court must give effect to Congress's intent. ${ }^{13}$ The second step of Cheuron requires that a court defer to the agency's interpretation offered by an administrative agency if Congress has not "directly addressed the precise question at issue."14 The clarity of the test signalled that the Court might have settled the issue of how courts should ad-

10 FEC v Democratic Senatorial Campaign Committee, 454 US 27, 39 (1981) ("[T]he task for the Court of Appeals was not to interpret the statute as it thought best but rather the narrower inquiry into whether the Commission's construction was 'sufficiently reasonable' to be accepted by a reviewing court."); Ford Motor Credit Co. v Milhollin, 444 US 555, 565 (1980) (Federal Reserve Board's interpretation of its governing statute controls unless it is "demonstrably irrational"); Packard Motor Car Co. v NLRB, 330 US 485, 485 (1947) (agreeing with a determination by the NLRB that foremen qualified as an appropriate bargaining unit under the National Labor Relations Act); Gray v Powell, 314 US 402, 412 (1941) (upheld an agency determination that a company's activities were subject to regulation by the Department of the Interior).

"11 Office Employees Int'l Union, Local No. 11 v NLRB, 353 US 313, 319 (1957) (rejecting NLRB's refusal to assert jurisdiction over labor unions as contrary to legislative intent).

${ }^{12} 467$ US 837 (1984).

1s Id at $842-43$. The opinion read:

When a court reviews an agency's construction of the statute which it administers, it is confronted with two questions. First, always, is the question whether Congress has directly spoken to the precise question at issue. If the intent of Congress is clear, that is the end of the matter; for the court, as well as the agency, must give effect to the unambiguously expressed intent of Congress.

Repeating accepted notions of the judiciary's role, the opinion also noted:

The judiciary is the final authority on issues of statutory construction and must reject administrative constructions which are contrary to clear congressional intent .... If a court, employing traditional tools of statutory construction, ascertains that Congress had an intention on the precise question at issue, that intention is the law and must be given effect.

Id at $843 \mathrm{n} 9$.

14 Id at 842-43.

If, however, the court determines Congress has not directly addressed the precise question at issue, the court does not simply impose its own construction on the statute, as would be necessary in the absence of an administrative interpretation. Rather, if the statute is silent or ambiguous with respect to the specific issue, the question for the court is whether the agency's answer is based on a permissible construction of the statute.

Later in the opinion, the Court stated that where Congress has left "gaps" for an agency to fill by regulation, "[s]uch legislative regulations are given controlling weight unless they are arbitrary, capricious, or manifestly contrary to the statute." Id at 843-44. 
dress agency interpretations of statutes they administer. ${ }^{15}$ The Cheuron decision was quickly recognized as one of the most important decisions in administrative law. ${ }^{16}$

Nevertheless, despite the apparent simplicity of the Cheuron test, courts have disagreed over how far Chevron's principle of deference extends and, in particular, how to reconcile it with the doctrine of stare decisis. ${ }^{17}$ When a court confronts a new agency interpretation that conflicts with a prior judicial construction of a statute, it must decide what use to make of that precedent. Before Chevron, a prior judicial construction was binding upon lower courts under the doctrine of stare decisis and upon later panels in a circuit which had previously considered the question under a practice known as "the law of the circuit."18 However, if a prior construction represented that earlier court's deference to an agency interpretation, how can that earlier construction continue to bind courts after Cheuron? Under the terms of Cheuron, if clear congressional intent does not demand a certain construction and if an agency reasonably construes the statute, then a court must defer to the agency's new interpretation.

In examining this issue, it helps to consider the related issue of whether administrative agency interpretations of statutes that are new or depart from a past interpretation should be given the

\footnotetext{
${ }^{15}$ Despite this seeming clarity, there is disagreement as to whether the Supreme Court has given effect to the standard established in Chevron. In a recent article, Thomas Merrill argues that "the Court does not regard Chevron as a universal test for determining when to defer to executive interpretations: the Chevron framework is used in only about half the cases that the Court perceives as presenting a deference question." Merrill, 101 Yale L J at 970 (cited in note 9). He notes that the "multiple factors" used by pre-Chevron courts to determine whether or not to defer to an agency have not disappeared; "to the contrary, the Court continues to rely upon them in many cases, despite their apparent irrelevance under Cheuron." Id.

${ }^{16}$ See Ronald M. Levin, Judicial Review of Administrative Action in a Conservative Era, 39 Admin L Rev 353, 356 (1987); Scalia, 1989 Duke L J at 512 (cited in note 7); Starr, 3 Yale $J$ Reg at 312 (cited in note 2). But consider the suggestion made by Judge Breyer, 38 Admin L Rev at 373 (cited in note 7). After describing the pre-Chevron context, which permits varying levels of deference to agency interpretations, he discusses the "simpler approach" advocated in Cheuron, and suggests that "[d]espite its attractive simplicity, however, this interpretation seems unlikely in the long run, to replace the complex approach described above ...." Judge Breyer's prediction is bolstered by the analysis in Professor Merrill's recent article. See note 15; Merrill, 101 Yale L J at 980-85, 1034-41 (cited in note 9).

${ }^{17}$ See Merrill, 101 Yale L J at 989-90 (cited in note 9).

18 "A panel decision is binding on district courts within the circuit and on other panels until overruled by the circuit en banc or by the Supreme Court." Rebecca Hanner White, Time for a New Approach: Why the Judiciary Should Disregard the "Law of the Circuit" when Confronting Nonacquiescence by the National Labor Relations Board, $69 \mathrm{NC} \mathrm{L}$ Rev 639, 672-73 (1991).
} 
same deference as longstanding agency interpretations. ${ }^{19}$ Before Chevron, courts often deferred to administrative agency interpretations that were longstanding, consistent, and contemporaneous with the passage of the statute, but scrutinized new interpretations more carefully. ${ }^{20}$ Although some Justices have supported this distinction between longstanding interpretations and new interpretations even after Cheuron," "if Cheuron is right, this position is wrong . . .."22 Administrative agencies are granted deference not because they are better able to find the one, true meaning of a statute, but because statutory ambiguities should be resolved by specialized administrators who are accountable to the electorate. ${ }^{23}$ If accountability lies behind the authority of an agency to interpret a statute, then an agency must be able to change its interpretation in response to pressure from those to whom it is accountable.

Although this reasoning may suggest that courts should defer even when an agency changes its longstanding interpretation of a statute, it is not so clear that an agency should be permitted to change its interpretation of a statute if an earlier interpretation had been identified by a court, perhaps the Supreme Court, as the

19 See Sunstein, 90 Colum L Rev at 2101-04 (cited in note 3).

${ }^{20}$ Id at 2101-02. See, for example, EEOC v Associated Dry Goods Corp., 449 US 590, 600 n 17 (1981); Andrus v Shell Oil Co., 446 US 657, 667-68 (1980) (deferring to contemporaneous agency interpretation). But see, Davies Warehouse Co. $v$ Bowles, 321 US 144, 156 (1944); Pittston Stevedoring Corp. v Dellaventura, 544 F2d 35, 49-50 (2d Cir 1976), aff'd as Northeast Marine Terminal Co., Inc. v Caputo, 432 US 249 (1977) (ignoring contemporaneous agency interpretation).

Although Professor Sunstein states that the "reasons for this distinction never have been entirely clear," he suggests that "[p]erhaps the special deference accorded to longstanding interpretations embodied an effort to import principles of stare decisis into administrative processes in order to protect reliance and expectations." Sunstein, 90 Colum L Rev at 2102 (cited in note 3).

"2 See INS v Cardoza-Fonseca, 480 US 421, 446 n 30 (1987), quoting Watt v Alaska, 451 US 259, 273 (1981) ("An additional reason for rejecting the INS's request for heightened deference to its position is the inconsistency of the positions the BIA has taken through the years. An agency interpretation of a relevant provision which conflicts with the agency's earlier interpretation is 'entitled to considerably less deference' than a consistently held agency view."). But see Rust v Sullivan, 111 S Ct 1759, 1769 (1991), quoting Chevron, 467 US at 862 ("This Court has rejected the argument that an agency's interpretation 'is not entitled to deference because it represents a sharp break with prior interpretations' of the statute in question.").

${ }^{22}$ Sunstein, 90 Colum L Rev at 2102 (cited in note 3). See also Scalia, 1989 Duke L J at 517 (cited in note 7) ("[T]here is no longer any justification for giving 'special' deference to 'long-standing and consistent' agency interpretations of law. That venerable principle made a lot of sense when we assumed that both court and agency were searching for the one, permanent, 'correct' meaning of the statute; it makes no sense when we acknowledge that the agency is free to give the statute whichever of several possible meanings it thinks most conducive to accomplishment of the statutory purpose.").

${ }^{23}$ Sunstein, 90 Colum L Rev at 2103 (cited in note 3). 
correct construction of the statute. Certainly, there would be "something unsettling about a world in which executive branch administrators could 'overrule' Supreme Court decisions." 24 Therefore, it is essential that a coherent and consistent approach be developed to respond to this conflict between the doctrine of stare decisis-which requires courts to follow prior constructions of statutes-and the mandate of Cheuron-which gives agencies responsibility for interpreting ambiguous statutory provisions.

A court could follow one of three approaches when presented with pre-Cheuron precedent. The first approach would be to simply accept any prior construction of a statute as binding on lower courts. ${ }^{25}$ Under the terms of Chevron, this approach appears clearly unacceptable. ${ }^{26}$ Earlier courts often deferred to an agency's interpretation of a statute. To hold that an earlier deferential ruling constitutes binding precedent after Chevron and trumps an agency's new interpretation ignores the strict standard established by Cheuron's first step: Only if there is clear congressional intent on an issue may a court replace an agency's construction with its own.

The second approach would grant an earlier holding precedential value based on what the earlier court believed it was doing. If an earlier court adopted its interpretation because it represented Congress's intent, then the prior interpretation would meet the Cheuron step one test and would be considered controlling precedent. If an earlier opinion identified the interpretation in question as one which Congress had explicitly or implicitly delegated to the agency, to which the earlier court deferred, then this would also be considered controlling precedent, requiring the present court to accept the new agency interpretation (as long as it was "reasonable") under Cheuron step two.

24 Merrill, 101 Yale L J at 989 (cited in note 9). See also Mesa Verde Construction Co. $v$ Northern California Dist. Council of Laborers, 861 F2d 1124, 1146-49 (9th Cir 1988) (Kozinski dissenting).

${ }^{25}$ When used in this Comment, the term lower courts also refers to other panels in a circuit which has already ruled on the issue.

${ }^{28}$ It has been argued that previous constructions made by the Supreme Court simply take precedence over any deference owed to administrative agencies demanded by Cheuron. Professor Merrill argues that this "outcome does not follow from the logic of Chevron, and must be counted as ... [a] qualification on that doctrine." Merrill, 101 Yale L J at 990 (cited in note 9). Although Professor Merrill suggests that the Court simply ignores Cheuron in such situations, this Comment argues that the Court is using a more complicated approach. However, Professor Merrill's argument may best explain the Court's decision in Lechmere, Inc. v NLRB, 112 S Ct 841 (1992). See Section I.D. 
This second approach suggests that if a court can determine that an earlier court had based its construction on clear congressional intent, it must follow that earlier construction under stare decisis. ${ }^{27}$ Or if a court can determine that an earlier court implicitly held that Congress had not directly spoken to the precise issue in question, it must bypass Cheuron step one and accept the agency's new interpretation under Chevron step two, as long as it is a reasonable interpretation of the statute. ${ }^{28}$

Of course, the primary difficulty encountered in following the approach outlined above lies in determining whether in fact an earlier court based its interpretation on what it considered to be clear congressional intent. That earlier court made its interpretation in a context which gave it final authority to determine a statute's meaning, whether or not Congress had spoken directly to the issue. ${ }^{28}$ Because of the difficulty inherent in discerning the intentions of an earlier court, a court may instead want to make a presumption that pre-Cheuron precedents are unreliable in the postCheuron context.

This suggests a third approach, which is outlined in Section II of this Comment. Under this approach, a court would consider prior rulings only as informative-not as binding precedent-and would examine each statute anew under the Chevron analysis. Chevron demands a reformulation of the role of stare decisis, because it marked a fundamental reconception of how to interpret public law.

\section{Using Precedent From Pre-Chevron Cases}

One possible approach to pre-Cheuron precedent after Chevron would attempt to translate the pre-Chevron opinion into a

${ }^{27}$ This is one reading of Maislin Industries v Primary Steel, Inc., 497 US 116 (1990). See Section I.A.

28 This is the approach taken in Mesa Verde, 861 F2d 1124. See Section I.B. A court might believe that an earlier court's interpretation had been based on deference to an agency rather than clear congressional intent, but that, in fact, Congress had directly addressed the precise issue in question. In that case, the court might want to introduce its reading of congressional intent as a Cheuron step one interpretation. This, however, is not a viable interpretative stance. It is hardly an acceptable presumption that the earlier court had either mistakenly ignored or deliberately rejected clear congressional intent in interpreting a statute and had instead deferred to an administrative agency's interpretation (or substituted its own interpretation).

"See, for example, FTC v Colgate-Palmolive Co., 380 US 374, 385 (1965) ("[W]hile informed judicial determination is dependent upon enlightenment gained from administrative experience," words setting forth "a legal standard . . . must get their final meaning from judicial construction."). 
post-Chevron analysis. This approach is suggested by one reading of the Supreme Court's decision in Maislin Industries, U.S., Inc. $v$ Primary Steel, Inc...$^{30}$ In Maislin, the Court held: "Once we have determined a statute's clear meaning, we adhere to that determination under the doctrine of stare decisis, and we judge an agency's later interpretation of the statute against our prior determination of the statute's meaning." 31 The Court stated that earlier interpretations of the statutory provision in question had been based on the statute's clear meaning and gave effect to Congress's central purpose in passing the Interstate Commerce Act (ICA). ${ }^{32}$ For these reasons, the Court held the new agency interpretation invalid because it conflicted with the prior construction of the statute, which constituted binding precedent. ${ }^{33}$ Therefore, one way of reading Maislin is that, in Chevron terms, the Court found that earlier decisions had implicitly held that the precise question at issue could be decided at Cheuron step one, because Congress's intent was clear.

\section{A. Reading Maislin}

In Maislin, the Court addressed a new policy implemented by the Interstate Commerce Commission (ICC) ${ }^{34}$ and upheld in five circuits. $^{36}$ This policy overturned a longstanding practice of the ICC that required a shipper to pay the shipping rate that its carrier had filed with the ICC even when it had privately negotiated a lower rate.

In this case, petitioner Maislin Industries, U.S., Inc., a bankrupt carrier, sought to recover undercharges from a shipper, respondent Primary Steel. Maislin's subsidiary Quinn Freight Lines had negotiated rates with Primary lower than Quinn's rates on file with the ICC. Relying on its decision in Negotiated Rates $I_{,}^{36}$ the

so 497 US 116 (1990).

${ }^{31}$ Id at 131.

32 Id at $130-31$.

s3 Id.

34 See NITL-Petition to Institute Rulemaking on Negotiated Motor Common Carrier Rates, 3 ICC2d 99 (1986) (Negotiated Rates I); NITL-Petition to Institute Rulemaking on Negotiated Motor Common Carrier Rates, 5 ICC2d 623 (1989) (Negotiated Rates In).

${ }^{3 s}$ See Delta Traffic Service, Inc. v Transtop, Inc., 902 F2d 101 (1st Cir 1990); Delta Traffic Service, Inc. v Appco Paper \& Plastics Corp., 893 F2d 472 (2d Cir 1990); Orscheln Bros. Truck Lines, Inc. v Zenith Electric Corp., 899 F2d 642 (7th Cir 1990); Maislin v Primary Steel, Inc., 879 F2d 400 (8th Cir 1989); West Coast Truck Lines, Inc. v Weyerhaeuser Co., 893 F2d 1016 (9th Cir 1990). The last four of these cases have been either vacated, reversed or withdrawn.

36 3 ICC2d 99 (1986). 
ICC determined that collection of the filed rate by Maislin would constitute an unreasonable practice under ICA $\S 10701,{ }^{37}$ and that " a finding that the carrier engaged in an unreasonable practice should, like a finding that the filed rate is unreasonable, disentitle the carrier to collection of the filed rate." ${ }^{38}$ The Eighth Circuit affirmed the approach taken by the ICC, ${ }^{39}$ concluding that because $\S 10701$ did not specifically address what practices were to be considered unreasonable and because the ICC's interpretation of $\S 10701$ was rational and consistent with the ICA, its new interpretation should receive deference under Chevron. ${ }^{40}$

The Supreme Court disagreed. It first pointed to a "century" of consistent interpretation of the ICA forbidding the "secret negotiation and collection of rates lower than the filed rate."41 The Court pointed out that Congress had not diverged from that interpretation, despite the extended opportunity to change the interpretation through legislation, implicitly suggesting that such a refusal indicated congressional approval of the interpretation. ${ }^{42}$ The Court concluded that the ICC's new interpretation was "flatly inconsistent with the statutory scheme as a whole."43 Noting that it had previously "determined [the] statute's clear meaning," the court chose to "adhere to that determination under the doctrine of stare decisis . . .."44

In support of its position the Court drew on precedent reaching from $1986^{45}$ back to $1895 .^{46}$ These cases manifested an unwavering interpretation of the ICA as prohibiting the collection of rates lower than the filed rate. Known as the "filed rate doctrine," this interpretation was stated most succinctly in Louisville \& Nashville Railroad Co. $v$ Maxwell:

Under the Interstate Commerce Act, the rate of the carrier duly filed is the only lawful charge. Deviation from it is not permitted upon any pretext. Shippers and travelers are charged with notice of it, and they as well as the carrier must

37 "A ... practice related to transportation or service provided by a carrier ... must be reasonable." 49 USC § 10701(a) (1982).

ss Maislin, 497 US at 129.

30 Maislin, 879 F2d at 405.

40 Id at 406.

11 Maislin, 497 US at 130.

42 Id at 135.

4s Id at 131.

"14. Id.

45 Square D Co. v Niagara Frontier Tariff Bureau, Inc., 476 US 409, 415-17 (1986).

46 Gulf, Colorado \& Santa Fe Ry. Co. v Hefley, 158 US 98, 101 (1895). 
abide by it, unless it is found by the Commission to be unreasonable. Ignorance or misquotation of rates is not an excuse for paying or charging either less or more than the rate filed. This rule is undeniably strict and it obviously may work hardship in some cases, but it embodies the policy which has been adopted by Congress in the regulation of interstate commerce in order to prevent unjust discrimination. ${ }^{47}$

The Court assembled a wide range of cases that supported the filed rate doctrine. ${ }^{48}$ The language of these cases implied that deference to the ICC was not central to the Court's maintenance of the filed rate doctrine. Rather, there is repeated emphasis on Congress's clear intent that the ICA was to prevent discriminatory pricing, and there is an absence of any language of deference. An example of the emphasis on congressional intent can be found in Keogh $v$ Chicago \& Northwestern Ry. Co.: "This stringent rule prevails, because otherwise the paramount purpose of Congress-prevention of unjust discrimination-might be defeated." ${ }^{\prime 49}$

The Maislin majority recognized that decisions of the ICC deserved deference, but not when its interpretation of a statute contradicted the statute's clear meaning: "Although the Commission has both the authority and expertise generally to adopt new policies when faced with new developments in the industry ... it does not have the power to adopt a policy that directly conflicts with its governing statute." had designed the statute in such a way as to require the filed rate doctrine, and that " '[a]ny other construction of the statute opens the door to the possibility of the very abuses of unequal rates which it was the design of the statute to prohibit and punish." "BI

473 US 94, 97 (1915) (quoted in Maislin, 497 US at 127).

${ }^{48}$ Southern Pacific Transp. Co. v Commercial Metals Co., 456 US 336, 352 (1982); Baldwin v Scott County Milling Co., 307 US 478, 484-85 (1939); Louisville \& Nashville Ry. Co. v Central Iron \& Coal Co., 265 US 59, 65 (1924); Kansas City Southern Ry. Co. v Carl, 227 US 639, 653 (1913); Armour Packing Co. v United States, 209 US 56, 81 (1908); Texas \& Pacific Ry. Co. v Abilene Cotton Oil Co., 204 US 426, 439 (1907); Texas \& Pacific Ry. Co. v Mugg, 202 US 242, 245 (1906).

to Maislin, 497 US at 126, quoting Keogh, 260 US 156, 163 (1922). See also Southern Pacific, 456 US at 344 ("This rule of strict adherence to statutory standards is in line with the historic purpose of the Interstate Commerce Act-to achieve uniformity in freight transportation charges, and thereby to eliminate the discrimination and favoritism that had plagued the railroad industry in the late 19th century.").

so Maislin, 497 US at 134-35 (citations omitted).

s1 Id at 130-31, quoting Armour Packing, 209 US at 81 (emphasis added). 
Justice Stevens dissented, arguing that the majority had ignored the demands of Cheuron..$^{52} \mathrm{He}$ claimed that the majority "fail[ed] to adhere ... to the teaching of Chevron" in dismissing it "by means of a conclusory assertion" despite the fact that the circuit courts had depended on Chevron in the cases below. ${ }^{53}$ In response to the plethora of supporting cases cited by the majority, Justice Stevens stated:

The fact that the Court has strictly enforced the filed rate doctrine in the many cases in which it served the agency's regulatory purposes provides no justification for enforcing the doctrine in a competitive market in which it frustrates the agency's attempt to carry out the plainly expressed intent of Congress. ${ }^{54}$

Justice Stevens further argued that neither the language of the statute $^{55}$ nor the regulatory scheme established by the ICA ${ }^{56}$ and modified by the Motor Carrier Act of 1980 justified the interpretation placed on the statute by the majority. Justice Stevens concluded that the ICC's determination that it would be an unreasonable practice for Maislin to recover the difference between the negotiated rates and the tariff rates from its customer "was unquestionably consistent with the plain language of the statute governing the Commission's authority." Juz Justice Stevens's regulatory argument was based on Congress's new intent to promote competition, which made the filed rate doctrine an "anachronism" in the motor carrier industry..$^{58}$

Justice Scalia rushed to the defense of the majority and the Cheuron principle in his concurrence. ${ }^{59} \mathrm{He}$ argued against Justice Stevens's interpretation of the statute and concluded that the text fully supported the filed rate doctrine.$^{60} \mathrm{He}$ suggested, moreover, that the majority was making a Cheuron step one decision. Justice

${ }^{62}$ Maislin, 497 US at 152 (Stevens dissenting).

ss Id.

st Id.

ss Id at 139-44.

se Id at 144-51.

${ }^{87}$ Id at 141.

s8 Id at 147. See generally, Motor Carrier Act of 1980, Pub L No 96-296, 94 Stat 793, codified at 49 USC § 10101 (1982).

${ }^{30}$ Maislin, 497 US at 136-38 (Scalia concurring).

6o Id at 136. Justice Scalia pointed out that "[w]hatever else may qualify as an unreasonable practice, under no sensible construction of that term could it consist of failing to do what the statute explicitly prohibits doing-viz., charging or receiving a rate different from the rate specified in a tariff." 
Scalia's concurring opinion, with its specific response to Justice Stevens's reading of the text of the statute, provided an example of how the majority opinion might have been better written. ${ }^{61}$ If, as it asserts, the majority believed that the Court had previously "determined [the] statute's clear meaning," ity concentrate only on providing myriad pre-Cheuron precedents, rather than showing the clarity of the statute? ${ }^{63}$

Although Justice Scalia argued that the Maislin majority based its decision on the text of the ICA and not on the authority of pre-Chevron interpretations, Maislin can be read as an argument that pre-Chevron authority can have precedential weight after Cheuron. Nevertheless, Maislin still would not answer conclusively the question of whether all, or only some, pre-Cheuron decisions are binding precedent.

The Maislin majority stated that if a statute's "clear meaning" had been determined, it would adhere to that interpretation, ${ }^{64}$ but it is not a simple matter to discover whether a prior court actually determined a statute's clear meaning or whether it deferred to the interpretation suggested by the agency. Mesa Verde Construction Co. $v$ Northern California District Council of Laborers clearly illustrates this difficulty. ${ }^{65}$ The Ninth Circuit considered whether it should defer to a new interpretation of a statute by the National Labor Relations Board (NLRB). Although the Supreme Court had upheld the NLRB's previous interpretation of the statute in two cases, ${ }^{86}$ the Ninth Circuit ruled that those cases had merely been an expression of deference to the NLRB's previous interpretation. ${ }^{67}$ Relying on Cheuron, the court ruled in favor of the NLRB's new interpretation, and, in the face of spirited dissents, held that the Supreme Court's earlier reading of the statute did not rise to the level set by Chevron step one. ${ }^{88}$

SI See Section II.

${ }^{62}$ Maislin, 497 US at 131.

${ }^{63}$ See Sunstein, 90 Colum L Rev at 2103-104 n 149 (criticizing majority for ignoring Chevron principles) (cited in note 3).

64 Maislin, 497 US at 131.

es 861 F2d 1124 (9th Cir 1988) (en banc).

${ }^{68}$ Jim McNeff, Inc. $v$ Todd, 461 US 260 (1983); NLRB v Local Union No. 103, Int'l Ass'n of Bridge, Structural \& Ornamental Iron Workers, AFL-CIO, 434 US 335 (1978) (Higdon).

${ }^{67}$ Mesa Verde, 861 F2d at 1130.

${ }^{68}$ Id. 


\section{B. Reading Mesa Verde}

Section 8(f) of the National Labor Relations Act (NLRA) ${ }^{69}$ permitted pre-hire agreements between construction unions and employers. These pre-hire agreements allowed contractors to arrange for a guaranteed work force before a particular construction job began. ${ }^{70}$ The NLRB had changed its earlier position that such pre-hire agreements could be unilaterally repudiated ${ }^{71}$ and decided that they could not be unilaterally repudiated prior to an NLRBconducted election in which the employees voted to reject or change their bargaining representative. ${ }^{72}$

In upholding the NLRB's new interpretation, the Mesa Verde court made a strong argument that the two prior Supreme Court decisions upholding the NLRB's earlier interpretation of $\S 8(f)-J i m$ McNeff, Inc. $v$ Todd $^{73}$ and NLRB v Local Union No. 103, Int'l Ass'n of Bridge, Structural \& Ornamental Iron Workers, $A F L-C I O$ (Higdon) ${ }^{74}$ - were merely expressions of deference to the NLRB. ${ }^{75}$ The Mesa Verde majority argued that the Supreme Court did not "definitively construe 8(f)" in either case. ${ }^{76}$ Instead, the majority continued, "the Court found that the Board's interpretation of $8(\mathrm{f})$ was an acceptable interpretation of the statute and that it reasonably implemented the purposes of the Act. The Court, therefore, deferred to the NLRB's interpretation of 8(f)."

The majority pointed to language in Higdon, which, in its opinion, gave a strong indication of deference by the Supreme Court. The majority quoted the Higdon Court's conclusion that the NLRB's construction of the NLRA "although perhaps not the only tenable one, is an acceptable reading of the statutory language

62 29 USC \& 158(f) (1982).

${ }^{70}$ Mesa Verde, 861 F2d at 1127.

${ }^{71}$ R.J. Smith Construction Co., 191 NLRB Dec (CCH) 693 (1971), enforcement denied as Local 150, Int'l Union of Operating Eng'rs, AFL-CIO v NLRB, 480 F2d 1186 (D C Cir 1973); Ruttmann Construction Co., 191 NLRB Dec (CCH) 701 (1971).

${ }_{72}$ Deklewa, 282 NLRB Dec (CCH) 1375, 1385 (1987), enforced as Int'l Ass'n of Bridge, Structural and Ornamental Iron Workers, Local 3 v NLRB, 843 F2d 770 (3d Cir 1988).

73 461 US 260 (1983).

74434 US 335 (1978).

${ }^{75}$ In Higdon, the Supreme Court upheld a ruling by the NLRB that an uncertified union with a $\$ 8(f)$ agreement with an employer committed an unfair labor practice when it picketed the employer to force it to abide by the pre-hire agreement, since a $\S 8(\mathrm{f})$ agreement is voidable until the union attains majority support. 434 US at 341,346 . In McNeff, the Court held that despite the fact that a $\$ 8(\mathrm{f})$ agreements may be repudiated at will, monetary obligations incurred by an employer to an uncertified union prior to repudiation survived. 461 US at 271-72.

76 861 F2d at 1129.

72 Id. 
and a reasonable implementation of the purposes of the relevant statutory sections."78 The Mesa Verde majority noted that the Higdon Court "recognized the expertise and experience of the [NLRB] in effectuating national labor policy as mandated by Congress and limited its review to whether the Board's interpretation of 8(f) was reasonable."78 The majority likewise considered $M c N e f f$ not to represent an independent construction of $\S 8(f)$, because $M c N e f f$ had merely relied on Higdon in ruling that $\S 8(f)$ agreements were voidable. ${ }^{80}$

Relying on deferential language in the two decisions and noting similar reasoning by the Third Circuit in Deklewa $v$ Int'l Ass'n of Bridge, Structural and Ornamental Ironworkers, Local $3,^{81}$ the Mesa Verde majority concluded that "neither Higdon nor McNeff preclude this court from adopting the view of the NLRB as expressed in Deklewa. Neither constitutes an independent construction of the statute." The court then accepted the NLRB's new interpretation because it appeared "consistent with the legislative history of section 8(f), as well as the dominant principles of employee free choice and labor relations stability."83 Higdon and $M c N e f f$, however, contain language that could support an argument that the Supreme Court was definitively construing $\S 8(\mathrm{f})$. In Judge Hug's dissenting view, Higdon deferred to the NLRB only in the sense that it gave "heightened consideration to the Board's arguments," and ultimately "passed judgment upon the meaning of section 8(f)" which is "binding under . . . stare decisis."84 Since Judge Hug found Higdon and McNeff to be based on clear con-

${ }^{78}$ Id, quoting Higdon, 434 US at 341.

79 Mesa Verde, 861 F2d at 1129.

${ }^{80}$ Id at 1129 , citing $M c N e f f, 461$ US at 266-67.

B1 Mesa Verde, 861 F2d at 1130 n 4.

8281 F2d at 1130. See also Deklewa, 843 F2d at 776:

In neither case has the Supreme Court adopted the Board's R.J. Smith interpretation of $\S 8(f)$ as definitive and binding. Indeed in Higdon, . . the Supreme Court . . . made clear that it was merely reviewing the Board's interpretation of $\S 8(f)$ and not substituting its own judgement or prescribing its own interpretation of the statute ....

While McNeff is not as explicit as Higdon in making it clear that the Supreme Court was merely reviewing the Board's interpretation and not establishing one of its own, nowhere in the McNeff opinion does the Court hold that the statute requires $\S 8(\mathrm{f})$ agreements to be voidable. Furthermore, $M c N e f f$ relies very heavily upon Higdon which did make it clear that the Court was doing no more than holding that the Board's reading of the act was reasonable.

ss Mesa Verde, $861 \mathrm{~F} 2 \mathrm{~d}$ at 1134.

84 Id at 1138 (Hug dissenting). The strongest language from Higdon that Hug cited states:

Congressional concern about coerced designations of bargaining agents did not evaporate as the focus turned to the construction industry. 
gressional intent and straightforward statutory interpretation, ${ }^{85}$ he read the Supreme Court's holdings in those cases as binding precedent. $^{\text {s8 }}$

The Mesa Verde majority based its holding on the proposition that if language indicating deference is present in a pre-Chevron opinion, a court must find that the earlier court had found no congressional intent on the precise question at issue. The Mesa Verde majority found that $M c N e f f$ and Higdon had implicitly held that this question required a Cheuron step two analysis, because Congress had not addressed the precise question of whether or not prehire agreements could be unilaterally repudiated. Consequently, this issue called for deference to a reasonable NLRB interpretation.

\section{One Possible Approach}

Considering the reading of Maislin outlined earlier ${ }^{87}$ together with Mesa Verde suggests one approach to pre-Chevron authority: a court should read an earlier opinion for direction as to whether a prior judicial interpretation of an agency-administered statute should be regarded as precedent after Chevron. A court would read an earlier opinion for two central elements: 1) presence of language

(n. 10) Congress was careful to make its intention clear that prehire agreements were to be arrived at voluntarily, and no element of coercion was to be admitted into the narrow exception being established to the majority principle.

Id at $1142 \mathrm{n} 2$ (Hug dissenting), quoting Higdon, 434 US at 347-48 n 10 and accompanying text (emphasis added by Hug).

Judge Hug found further support for his position in McNeff. There, the strongest language reads:

In upholding the Board's view that a union commits an unfair labor practice by picketing to enforce a prehire agreement before it has majority status, we noted in Higdon that this view protects two interests that Congress intended to uphold when it enacted $\S 8(f)$.

[O]ur decision in Higdon promotes Congress' "intention ... that prehire agreements were to be arrived at voluntarily ...." In accord with this intention, we approved the Board's conclusion that a "prehire agreement is voidable" "until and unless [the union] attains majority support in the relevant unit."

Mesa Verde, 861 F2d at 1143, quoting McNeff, 461 US at 267-69 (citations omitted) (emphasis added by Hug).

Judge Hug quoted further from $M c N e f f$, emphasizing language that points to congressional intent and that refers to prehire agreements "as being voluntary and voidable with the undoubted right of a party to repudiate the agreement prior to the union achieving majority status." Mesa Verde, 861 F2d at 1143-44 (Hug dissenting).

ss Mesa Verde, $861 \mathrm{~F} 2 \mathrm{~d}$ at 1144.

so Id.

${ }^{82}$ See Section I.A. 
suggesting that the court believed it was effectuating congressional intent, and 2) absence of language that indicates deference to the relevant agency.

One of these elements would not suffice; language in $M c N e f f$ hinting that the Court had looked to Congress's intent in finding $\S 8(f)$ agreements voidable did not persuade the Mesa Verde majority. ${ }^{88}$ Only when there is clear language stating that Congress had spoken to the issue, combined with an absence of language suggesting deference to the agency or suggesting that the court considered alternative solutions, would a pre-Chevron decision be able to survive the scrutiny required by Cheuron.

Taking Maislin and Mesa Verde together suggests that there should be a strong presumption that pre-Chevron precedent does not govern unless the prior interpretation's reliance on congressional intent has been clearly expressed. The Ninth Circuit interpreted Maislin very narrowly in a later case:

Maislin established an exception to the usual deference accorded an agency only where the agency's interpretation of statutory language conflicts with well established Supreme Court precedents . . . . The ICC ruling here at issue is not "flatly inconsistent with the statutory scheme as a whole" as it was in Maislin. ${ }^{\mathbf{8 9}}$

This understanding of Maislin places the presumption on the side of deference to the agency. This approach, while workable, has drawbacks. A court can read prior opinions however it wants. If a court prefers the prior construction of a statute, it can search an earlier opinion for language suggesting that the earlier court was interpreting the statute based on congressional intent. If a court prefers an agency's new interpretation, it can search the prior opinion for signs of deference.

The same indeterminacy may obtain in the interpretation of statutes themselves. Obviously, a court, whenever faced with a new agency interpretation that it does not like, could claim to find clear congressional intent requiring a different interpretation of the statute and so prevent the agency's interpretation from receiving deference under Cheuron step two. In doing so, it would be construing a statute in the way it thinks "best" despite the clear demands of the Chevron decision. But language contained within an opinion may be more malleable than typical statutory language. As is evi-

${ }^{83}$ Mesa Verde, 861 F2d at 1142-44 (Hug dissenting).

82 Int'l Brotherhood of Teamsters v ICC, 921 F2d 904, 907 (9th Cir 1990). 
dent from the disagreement between Judge Hug's dissent in Mesa Verde and the Mesa Verde majority, there is ample opportunity to make a prior opinion say what one wants. ${ }^{90}$ Furthermore, a discussion of whether an opinion reveals clear congressional intent is one step removed from the actual question asked by Chevron: Does the statute reveal clear congressional intent? It is more straightforward to determine whether Congress had spoken directly to the issue than to decide whether an earlier court had found that Congress had spoken directly to the issue, especially when that court's opinion was written at a time when courts did not focus their reasoning on that particular question. Although prior opinions might be granted some precedential value even after the context has been changed by Chevron, disputing a prior opinion's view on a question, rather than disputing the question itself, engenders a lack of respect for the law, thereby frustrating one of the central aims of stare decisis. ${ }^{91}$

\section{A Refinement of Mesa Verde: Lechmere, Inc. $v$ NLRB}

Maislin can be read as permitting lower courts to ignore preChevron interpretations of statutory provisions that were not based on clear congressional intent. If Maislin is read that way, lower courts may evaluate pre-Cheuron authority under the approach used by the Mesa Verde majority and overturn pre-Chevron interpretations based on deference to an administrative agency. ${ }^{92}$

A possible refinement to this approach was suggested last term in Lechmere, Inc. $v$ NLRB.$^{93}$ In Lechmere, the Court struck down a new NLRB interpretation of $\S 7$ of the NLRA, ${ }^{94}$ which had initially been expressed in the NLRB's opinion in Jean Country. ${ }^{95}$ The Court held that this new interpretation was inconsistent with

90 See text accompanying notes $65-86$.

91 White, 69 NC L Rev at 671 (cited in note 18).

22 See Sections I.A-I.C.

2s $112 \mathrm{~S}$ Ct 841 (1992).

94 29 USC § 157 (1982) ("Employees shall have the right to self-organization, to form, join, or assist labor organizations ....").

${ }^{25} 291$ NLRB Dec (CCH) 11 (1988). Jean Country addressed the rights of nonemployee union agents to enter an employer's property in order to organize employees and established a three factor balancing test which takes into account "[1] the degree of impairment of the Section 7 right if access should be denied ... [2] the degree of impairment of the private property right if access should be granted.... [3] the availability of reasonably effective alternative means . . . ." Id at 14 . 
its interpretation of $\S 7$ as stated in NLRB $v$ Babcock \& Wilcox Co. ${ }^{98}$

In Babcock, the Court had overturned the NLRB's determination that nonemployee union organizers should have the right to distribute union information on the employer's premises. ${ }^{97}$ The NLRB believed such a right was necessary to give effect to the employees' $\$ 7$ right to self-organization. ${ }^{98}$ The Babcock Court stated that nonemployee organizers should only be allowed to approach employees on an employer's property "if the location of a plant and the living quarters of the employees place the employees beyond the reach of reasonable union efforts to communicate with them ....."99

Although the Lechmere majority conceded that "the NLRB is entitled to judicial deference when it interprets an ambiguous provision of a statute that it administers," 100 and cited Chevron, it seemed to advocate the position that prior interpretations of a statute by the Court would trump any new NLRB interpretation: "Before we reach any issue of deference to the Board, however, we must first determine whether Jean Country . . . is consistent with our past interpretation of $\S 7 . " 101$ The Court then cited to Maislin: "Once we have determined a statute's clear meaning, we adhere to that determination under the doctrine of stare decisis, and we judge an agency's later interpretation of the statute against our prior determination of the statute's meaning." 102

The majority also stated that it believed that the Babcock Court, "[b]y reversing the Board's interpretation of the statute for failing to distinguish between the organizing activities of employees and nonemployees, [was] saying, in Chevron terms, that § 7 speaks to the issue of nonemployee access to an employer's property."103 However, the Lechmere majority did not discuss how the earlier interpretation in Babcock was based on clear congressional intent. In fact, Babcock contained no language indicating that the Court believed that it was giving effect to Congress's intent. The Court in Babcock, after "recogniz[ing] . . . that the Board has the responsibility of 'applying the Act's general prohibitory language

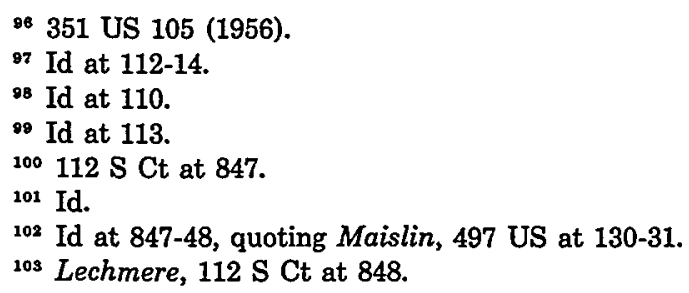


in the light of the infinite combinations of events which might be charged as violative of its terms," "104 and stating its reluctance "to overturn an administrative decision," 105 simply overturned the NLRB decision at issue on its own judgment, ${ }^{106}$ reflecting an earlier conception of the Court's authority and responsibility for final statutory interpretation. ${ }^{107}$ The majority in Lechmere held that stare decisis can overcome the demands of Chevron, as long as the prior holding was based on the statute's "clear meaning," but, unlike the majority in Maislin, it did not make any effort to show how the earlier interpretation of $\S 7$ in Babcock was based on the statutory provision's "clear meaning" or Congress's intent.

Justice White's dissent took the majority to task for this remarkable reading of Chevron, arguing that " $B a b c o c k$ is at odds with modern concepts of deference to an administrative agency charged with administering a statute . . . Babcock did not ask if Congress had specifically spoken to the issue of access of third parties ...."108 Justice White then noted that if Babcock had come up for decision in the post-Cheuron era, the Court would have deferred to the NLRB, and even if the NLRB had made one interpretation and then changed to another, the Court would have accepted that change. ${ }^{109}$ Justice White concluded:

The more basic legal error of the majority today, like that of the Court of Appeals in Cheuron, is to adopt a static judicial construction of the statute when Congress has not commanded that construction. ... By leaving open the question of how $\S 7$ and private property rights were to be accommodated under the NLRA, Congress delegated authority over that issue to the Board, and a court should not substitute its own judgment for a reasonable construction by the Board. ${ }^{110}$

If Lechmere indicates that the Court intends to modify the standard established by Maislin, then Cheuron will be weakened considerably. Although the same term is used by both Maislin and Lechmere-"clear meaning"-the Maislin majority made a strong case that its interpretation of the ICA was based on Congress's intent in passing the statute. Lechmere made no argument that Con-

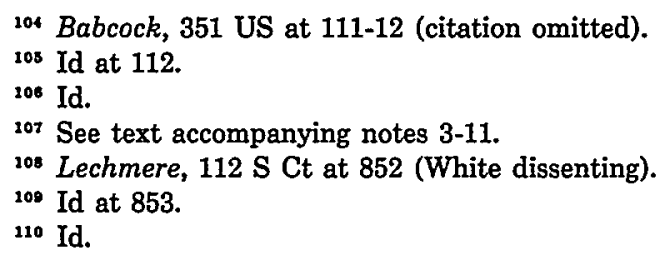


gress had intended such an interpetation of $\S 7$ of the NLRA. If a court can follow pre-Chevron precedent by making the barest of arguments that the statute's clear meaning had been determined by the earlier court, a court has wide latitude to do as it wishes with new agency interpretations. Having this level of indeterminacy strikes against the primary value of the doctrine of stare decisis-certainty of the law-and strikes against the primary goal of Cheuron-delegation of the responsibility for interpreting the statutes they administer to administrative agencies.

Such a reading of Maislin would seem to be a powerful argument against this approach to pre-Chevron authority. However, it is not clear that Lechmere was intended to change the requirements of Maislin, as the Lechmere majority rested its holding on Maislin without further discussion. Perhaps Lechmere only indicated an anomalous reading of Maislin, not a permanent change in the thinking of the Court on pre-Cheuron precedents, and as such should not be considered a redefinition of the Maislin approach. ${ }^{111}$

But another possibility should be considered: Lechmere may, in fact, indicate the Court's final position on the interaction of preCheuron authority with the demands of Chevron. Thomas Merrill has suggested that the Court has gradually moved away from the original requirement of Cheuron's first step-that unless "Congress [had] directly spoken to the precise question at issue"112 a court should defer to a reasonable agency interpretation-and moved to progressively less strict standards-such as whether a statute has a "plain meaning." "113 Professor Merrill argues that "[t]he [Court's] movement from 'specific intention' to 'plain meaning' to 'plain meaning considering the design of the statute as a whole' is but one short step away from 'best meaning." "114

${ }^{211}$ This is how the D.C. Circuit treated Lechmere in a recent case. In US Postal Service $v N L R B, 969$ F2d 1064 (DC Cir 1992), the court rejected the argument made by the Postal Service, based on Lechmere, that a reviewing court must first determine whether an NLRB interpretation of a statute is consistent with Supreme Court precedent before it can defer to an NLRB interpretation. The court stated that all the Supreme Court had done in Lechmere was read "Babcock as saying, in Chevron terms, that Congress had directly spoken to the question at issue." Id at 1070. Whether or not the Lechmere majority was actually concerned with whether Congress had spoken to the precise question at issue in Lechmere is debatable, but the D.C. Circuit appeared willing to accept that it was in order to preserve the Cheuron test when considering new agency interpretations that conflict with pre-Cheuron authority.

${ }^{212}$ Cheuron, 467 US at 842.

${ }^{113}$ Merrill, 101 Yale L J at 990 (cited in note 9).

${ }^{114}$ Id at 991 . Professor Merrill points out that Justice Scalia has expressly discussed the consequences of moving from a concentration on Congress's intent to a concentration on the "plain meaning" of the text of a statute: "One who finds more often (as I do) that the 
If the Court has chosen to shift its requirement for Chevron step one from specific congressional intent to the plain language of a statute, then Lechmere makes perfect sense. Any time the Court finds that an earlier interpretation of a statute was based on the statute's so-called clear meaning, then that interpretation would meet the requirements of Chevron's first step and would be binding precedent.

Such a rule, although perhaps not problematic for the Supreme Court (it, after all, would be the final authority on whether the earlier construction was based on clear meaning), poses serious problems for lower courts. It is not a simple task to determine whether an earlier court based its construction of a statute on clear congressional intent. It is a far more difficult task to determine conclusively whether language in an earlier Supreme Court opinion indicates that the Court relied on the "clear meaning" of a statute. ${ }^{115}$ Lechmere gives lower courts no guidance as to how they should go about determining whether an earlier Supreme Court construction rested on the plain language of a statute. Lower courts might try to duck the issue by upholding all Supreme Court precedents which conflict with new agency interpretations, but this solution would appear to violate grossly the Cheuron mandate. ${ }^{116}$ If Lechmere does signal a redefinition of Maislin, the need for an alternate approach for lower courts is apparent as a practical matter. ${ }^{117}$

meaning of a statute is apparent from its text and from its relationship with other laws, thereby finds less often that the triggering requirement for Cheuron deference exists." Id, quoting Scalia, 1989 Duke L J at 521 (cited in note 7). Professor Merrill concludes that Justice Scalia's approach "would dramatically transform Cheuron from a deference doctrine to a doctrine of antideference." Merrill, 101 Yale $\mathrm{L} J$ at 992 (cited in note 9).

115 Consider Justice White's point in Lechmere concerning the statute at issue: If the Babcock Court, and the Lechmere majority, had inquired into how the NLRA $\$ 7$ dealt with the access rights of non-employee union organizers, "the only basis for finding statutory language that settled the issue would have been the language of $\S 7$, which speaks only of the rights of employees; i.e., the Court might have found that $\S 7$ extends no access rights at all to union representatives." Lechmere, $112 \mathrm{~S} \mathrm{Ct}$ at 852 (White dissenting). More simply, how did the majority in Lechmere find a "clear language" argument in a statute that made no mention of the rights in question?

116 See text accompanying note 26.

117 The question of whether all pre-Chevron authority should be considered binding precedent is an extremely serious political issue due to the change of administration. As administrative agencies switch from Republican to Democratic control, there will likely be an attempt made to reverse many interpretations made by agencies during the Reagan-Bush era. If the Lechmere approach remains the defining approach of a judiciary now dominated by Reagan-Bush appointees, many agency interpretations made during the early years of the Reagan Revolution that were upheld by the Supreme Court and the circuit courts at the time could be considered binding precedent. If, however, interpretations which are not 


\section{Understanding Pre-Chevron Authority in a NeW INTERPRETative CoNTEXT}

Justice Scalia's reading of Maislin conflicts with the reading proposed by the Lechmere majority. Scalia's Maislin concurrence answered Justice Stevens's dissent, which excoriated the Maislin majority for sacrificing the Cheuron principle while mistakenly relying on pre-Cheuron authority. ${ }^{118}$ Justice Scalia argued that the majority had correctly relied on earlier decisions upholding the filed rate doctrine ${ }^{119}$ because those decisions had been based on the text of the Interstate Commerce Act. ${ }^{120}$ Justice Scalia seemed to argue that Maislin was rightly decided not because it upheld preCheuron precedent, but because the Maislin majority (like the Courts in the precedents which it cited) had correctly read the ICA as requiring the maintenance of the filed rate doctrine.

Justice Scalia's reading of the majority opinion in Maislin is supported by the majority's statement that the ICC's interpretation of the statutory provision in question was "contrary to the language and structure of the statute as a whole ...."121 The Court further argued that "[b]y refusing to order collection of the filed rate solely because the parties had agreed to a lower rate, the ICC has permitted the very price discrimination that the Act by its terms seeks to prevent." ${ }^{22}$ Although the majority quoted preChevron opinions to support its argument, the Maislin majority can also be seen as making a new Cheuron step one decision that the ICC's interpretation of the statutory provision in question was in conflict with clear congressional intent behind the ICA. This reading of Maislin says that a court should refuse to defer to a new agency interpretation only when a particular interpretation of a statute is clearly demanded under Cheuron step one. The key inquiry then is not what an earlier court thought it was doing in interpreting a statute, but whether in fact that earlier interpretation is demanded by clear congressional intent. If so, that earlier interpretation is considered binding precedent, but only because it meets the Cheuron step one test. If not, a new, reasonable agency interpretation should be accorded deference by the reviewing

clearly based on congressional intent are not considered binding precedent, it will be much easier for Clinton appointees to change the direction of administrative agencies.

11 Maislin, 497 US at 151-53 (Stevens dissenting).

118 Id at 136 (Scalia concurring).

${ }^{120}$ Id at $136-38$.

${ }^{121}$ Id at 130.

${ }_{122}$ Id (emphasis added). 
court. In other words, a court, when confronted with a new agency interpretation that conflicts with pre-Cheuron authority, must simply apply the Chevron test to the new interpretation.

This approach makes sense because Chevron dramatically changed the understanding of deference to administrative agencies. Prior to the decision in Chevron, a court was always free to substitute its construction of a statute for that suggested by an administrative agency. Thus, when an opinion said "deference to an agency interpretation," it perhaps meant something like "respect for an agency's expert opinion," but certainly not "abdication of authority and responsibility for interpretation."123

But the Chevron Court's "deference" is a much stronger concept. If there is no "clear congressional intent" and the agency's interpretation is "reasonable," then "a court may not substitute its own construction" for that advanced by the agency. ${ }^{124}$ In the changed interpretative context established by Chevron, deference means not simply that a court must consider an agency's interpretation, but that it "must give controlling weight to that interpretation" in certain well-defined situations. ${ }^{125}$

If Chevron has changed the meaning of deference, so too has it changed the meaning of the phrase "congressional intent" as used in judicial opinions. In the pre-Cheuron interpretative context, a court faced a statute with the responsibility of determining its "one, permanent, 'correct' meaning." look to the agency interpretation as a suggestion of what this

\footnotetext{
12s See Starr, 3 Yale J Reg at 296 (cited in note 2). Former Judge Starr argues that, before Chevron, when an agency's interpretation was consonant with that made by the Court, it may have been no more than a "happy coincidence." He concludes: "To defer to an agency's interpretation, then, was merely to give some weight to its interpretation."

${ }^{224}$ Cheuron, 467 US at 843-44.

${ }^{125}$ Starr, 3 Yale J Reg at 296 (cited in note 2). See also Farina, 89 Colum L Rev at 45663 (cited in note 3). Judge Starr points out that this new definition of deference eliminated a particularly troublesome ambiguity in Supreme Court jurisprudence:

Not only were there two conflicting lines of cases, but the Court failed to formulate any consistent rationale explaining why it sometimes used one approach and sometimes the other. Not surprisingly, this led several commentators to suggest that the deference standard was being applied in a result-oriented manner, with judges making independent interpretations and then invoking the principle only when it was convenient. Justice Marshall, dissenting from the Court's decision to reject an agency interpretation of a statute in Industrial Union Department, AFL-CIO v. American Petroleum Institute, argued that by ignoring precedent calling for judicial deference, the Court had given credence to the "frequently voiced criticism" that the deference principle is honored "only when the Court finds itself in substantive agreement with the agency action at issue."
}

Starr, 3 Yale J. Reg at 293-94 (cited in note 2) (citations omitted). ${ }^{126}$ Scalia, 1989 Duke L J at 517 (cited in note 7). 
meaning might be. If it accepted the agency interpretation it would be inclined to cite precedent from the "deference" line of cases. ${ }^{127}$ If it chose not to accept the agency interpretation, it could simply "say what the law is." 128 Therefore, a court might well claim in its opinion that it was using traditional methods of statutory construction to determine "congressional intent," whether or not it believed that Congress intended only one possible interpretation. Because of this earlier attitude towards the role of the judiciary in statutory construction, pre-Chevron opinions which claim to base a statutory construction on so-called "congressional intent" may not rise to the level of congressional intent needed to satisfy step one of the Cheuron analysis.

Because of the inherent difficulty in matching pre-Chevron language with post-Cheuron requirements, both the reading of Maislin suggested in Section I.A and the approach used by the Mesa Verde court are unsatisfactory. "Deference" in pre-Cheuron opinions does not mean "deference" as defined by Cheuron. "Congressional intent" in an opinion does not necessarily mean that level of clarity required by Chevron, but perhaps "mean[s] no more than that the panel regarded it as the better reading."129

A better approach than those described in Section I would be to presume that no pre-Chevron judicial construction of an agencyadministered statute which claims to be based on congressional intent actually meets the Chevron step one test. ${ }^{130}$ Every new agency

127 See Starr, 3 Yale J Reg at 293-94 (cited in note 2).

${ }_{128}$ See Marbury $v$ Madison, 5 US (1 Cranch) 137, 177 (1803). See Merrill, 101 Yale L J at 972 (cited in note 9). Professor Merrill points out that the "default rule was one of independent judicial judgment." Even when confronted by an agency interpretation of a statute it administered, "[d] eference to the agency interpretation was appropriate only if a court could identify some factor or factors that would supply an affirmative justification for giving special weight to the agency views."

${ }^{129}$ Clinchfield Coal Co. v Federal Mine Safety and Health Commission, 895 F2d 773, 777 (DC Cir 1990). See Section II.A.

130 This approach might seem to threaten values imbedded in the doctrine of stare decisis to an unacceptable extent. The Supreme Court has shown a "general reticence to overrule precedents construing statutes," perhaps on the theory that "congressional failure to enact legislation reversing a judicial decision indicates Congress' approval of the Court's interpretation of an earlier statute." Lawrence C. Marshall, "Let Congress Do It": The Case for an Absolute Rule of Statutory Stare Decisis, 88 Mich L Rev 177, 181, 184 (1989). In this article, Professor Marshall argues for an absolute rule of statutory stare decisis, which would require Congress to again become an "active participant in [the] ongoing process of statutory lawmaking." Id at 183, 200-19. By putting Congress on notice that only it can change statutory constructions made by the judiciary, Congress will be required to address any such constructions that occasion public displeasure. Id.

Depending on how one views the reach of a policy of strict statutory stare decisis, however, it can be indifferent or inimical to the Chevron principle. On the one hand, if one 
interpretation of a statute would, therefore, require a full Chevron analysis.

Using this approach, the construction of a statute in an earlier opinion would have precedential value in only one situation. It would stand as a valid alternative reading of the statute, requiring that a subsequent court either accept it under Chevron step one as the one meaning required by clear congressional intent, or accept it as a possible reading under Cheuron step two. A court could not find that Congress had spoken directly to the issue at hand and construe the statute in opposition to the prior interpretation. In other words, a court could not find that Chevron step one requires a particular interpretation but arrive at a result different from the earlier case. To do so would presume that the earlier court ${ }^{131}$ had either mistakenly or deliberately ignored congressional intent in the earlier decision. ${ }^{132}$ Although it is possible that this could happen (courts, after all, do make mistakes), such a presumption would not be possible under the doctrine of stare decisis. It is not for lower courts to determine that higher courts erred. ${ }^{133}$

simply says that any constructions of agency-administered statutes based on clear congressional intent should be followed under the doctrine of stare decisis, then various arguments as to how strictly the Court should adhere to its own precedents construing statutes apply to these precedents as well and do not seem to threaten any values inherent in the Cheuron principle. See William N. Eskridge, Interpreting Legislative Inaction, 87 Mich L Rev 67 (1988), for another view on this issue.

On the other hand, if one says that no statutory construction made by the Court should be overruled-as long as it has withstood congressional reversal through legislation for a sufficient period of time-then the Cheuron principle would be seriously limited. It can be argued that this approach was the basis for the Court's decisions in Maislin and Lechmere; both were longstanding interpretations from which "Congress ha[d] not diverged." Maislin, 497 US at 131. See text accompanying notes 40-42 and 93-102.

However, the question of whether or not to accept this approach is merely a dispute about the underlying wisdom of Cheuron. To maintain that only Congress has the power to overrule Supreme Court precedents construing statutes, even those precedents that address issues expressly delegated to administrative agencies by Congress, is to argue that the underlying responsibility for interpreting such statutes should lie with the courts and not with the administrative agencies. There is not, of course, unanimity on whether Chevron was "right"; however, if one accepts the Cheuron principle, then, at the very least, statutory stare decisis should be limited to those statutory constructions based on congressional intent. See text accompanying notes 20-27.

${ }^{131}$ Which, in this situation, would be a higher court or a prior panel of a circuit court.

${ }^{232}$ See text accompanying note 29 .

${ }^{133}$ Higher courts can overrule lower courts, of course. But if, for instance, the Supreme Court were considering a pre-Chevron construction of a statute made by a circuit court, none of the preceding discussion is necessary. The Supreme Court would simply overrule the prior decision, whether it found that the interpretation was a Cheuron step one or step two. 
A. Clinchfield Coal and the New Interpretative Context

The D.C. Circuit addressed the question of how to deal with pre-Chevron precedent in Clinchfield Coal Co. $v$ Federal Mine Safety and Health Commission. ${ }^{\mathbf{1 3 4}}$ In Clinchfield, the D.C. Circuit considered an appeal from an order of the Federal Mine Safety and Health Commission directing Clinchfield Coal to pay a week's salary to workers idled after an explosion in one of its mines. The Commission closed down the mine under $\S 107$ (a) of the Federal Mine Safety and Health Act of $1977,{ }^{135}$ which authorizes shutdown of a mine when an "imminent danger" is discovered. The United Mine Workers filed a claim under $\S 111$ of the Act, which provides for compensation of up to one week's pay to miners out of work due to the closure of a mine under a $\S 107$ order issued "for a failure of the operator to comply with any mandatory health or safety standards."136

Clinchfield contended that the $\S 111$ claim was precluded by the fact that the $\S 107$ order had not specified a safety violation. ${ }^{137}$ The Commission rejected this position, noting that it had issued citations to Clinchfield for safety violations that had caused the explosion-upon completion of the Commission's investigation, nine months after the mine closure. ${ }^{138}$ The court accepted the Commission's interpretation of $\S 111$ as requiring compensation if the violations later cited had caused the danger underlying the $\S$ 107 order. $^{139}$

However, in an earlier decision, District 6, UMWA v United States Dept. of Interior Board of Mine Operations Appeals, ${ }^{140}$ the D.C. Circuit had found that the predecessor provision of $\S 111$, which had identical language, permitted compensation only if a shutdown was "actually ordered because of" a type of a mine operator's failure that was covered at that time. Clinchfield contended that the court could not alter the law of the circuit, and was required to find that Clinchfield was not liable to the idled miners.

The court refused to accept this contention, arguing that in the new interpretative context created by Chevron the seemingly clear language of the District 6 court was not controlling prece-

\footnotetext{
134 895 F2d 773 (DC Cir 1990).

13530 USC \& 817(a) (1982).

${ }^{136} 30$ USC $\S 821$ (1982).

137 Clinchfield, $895 \mathrm{~F} 2 \mathrm{~d}$ at 775.

138 Id at 774.

139 Id at 777.

${ }^{140} 562$ F2d 1260, 1263 (DC Cir 1977).
} 
dent. ${ }^{141}$ The District 6 court had said, however, that the Commission's earlier interpretation was not "simply a reasonable reading of an ambiguous statute, but [ ] one 'compell[ed]' by the language and legislative history." ${ }^{42}$ The Clinchfield court argued that "[i]n doing so, however, [the District 6] court relied on a narrower concept of judicial deference than what Cheuron now plainly requires."143 The Clinchfield opinion pointed to language used by Judge Leventhal in his District 6 concurrence which it took to be the pre-Cheuron approach to statutory interpretation: "Questions of legislative intent require the courts, in the last analysis, to reconstruct how the legislature would have decided the specific issue if it had been specifically addressed by the legislature."144 Judge Leventhal's suggested approach, together with "the panel opinion's own stated purpose 'to determine which interpretation Congress intended," convinced the Clinchfield court that the District 6 panel's "conclusion that the language and history 'compell[ed]' the no-compensation result [meant] no more than that the panel regarded it as the better reading." ${ }^{45}$

The Clinchfield court held that "[s]uch a finding is not enough to bind the Commission under Chevron,"146 and explained how Chevron had established a new context in which language used in earlier opinions may not mean what it appears to say:

The concept of review invoked by Judge Leventhal overlooked the possibility that Congress meant no more than to allow the agency to select among reasonable interpretations. Cheuron presumes this to have been the case unless Congress has spoken clearly. . . . Thus, while under District 6 we must assume that the Commission's former view was the better one, that decision is not a finding that Congress clearly resolved the issue, and it leaves the Commission free to choose the other if reasonable. ${ }^{147}$

142 Clinchfield, 895 F2d at 777-78.

142 Id at 777, quoting District 6, $562 \mathrm{~F} 2 \mathrm{~d}$ at 1266.

14s Clinchfield, 895 F2d at 777. See also National Fuel Gas Supply Corp. v Federal Energy Regulatory Comm'n, 899 F2d 1244, 1248 (DC Cir 1990) ("But even if [an earlier] case had directly addressed that question . . . as a pre-Chevron decision, [it] would not foreclose the Commission from reinterpreting an ambiguity in its organic statute.") (emphasis in original).

144 Clinchfield, 895 F2d at 777, quoting District 6, 562 F2d at 1268 (Leventhal concurring).

${ }^{145}$ Clinchfield, $895 \mathrm{~F} 2 \mathrm{~d}$ at 777 (citations omitted), quoting District 6, $562 \mathrm{~F} 2 \mathrm{~d}$ at 1265.

16 Clinchfield, $895 \mathrm{~F} 2 \mathrm{~d}$ at 777.

147 Id at 777-78 (citations omitted). 


\section{B. A Presumption of Incommensurability}

A better approach to the problem of pre-Chevron authority after Chevron is reflected in the Clinchfield decision: a court would presume that a prior judicial interpretation of a statute cannot be binding precedent in the changed interpretative context brought about by the Cheuron decision. When confronted with a new agency interpretation of a statute previously construed by a higher court, a court would redo the Chevron two step test. This approach is better because it frees courts to give effect to the values inherent in Cheuron; courts will not be bound by decisions made by earlier courts which may not have had the same respect for administrative agency authority over statutory interpretation that is the hallmark of Cheuron.

Under either the Clinchfield approach advocated in this Comment or the Mesa Verde approach, a judge might look at the previous opinions and determine whether there was clear congressional intent. Perhaps, the only difference for a judge would come in framing an opinion to justify his decision. Under the approach suggested by the Clinchfield decision, a judge would discuss whether clear congressional intent exists. Under the Mesa Verde approach, a judge would discuss whether the prior opinions revealed that the courts had found congressional intent satisfactory to meet the Cheuron step one standard.

Under the Mesa Verde approach a court would still have to present an argument as to what Congress's intent was, but would have to do so in an oblique discussion about how the earlier court had successfully discerned that intent. If one accepts the premise of the Clinchfield court, it is not possible to learn whether or not an earlier court was holding that Congress had spoken directly to the issue, since an earlier court was not operating in the context created by Chevron in which clear congressional intent on the precise question at issue is the only consideration which can overcome the presumption of deference to reasonable agency interpretations. However, even if one does not accept the premise of the Clinchfield court, the attempt to substantiate congressional intent behind a statute by arguing from earlier opinions rather than from the statute itself is of dubious worth.

Using the Clinchfield approach, as opposed to the Mesa Verde approach, would require courts to concentrate more closely on arguments about congressional intent, rather than arguments about judicial intentions as revealed by earlier opinions. This would support Cheuron's central purpose: leaving to administrative agencies 
responsibility and authority for the interpretation of statutes which they administer.

Despite arguments that the Supreme Court has not followed the Chevron principle consistently when it has considered agency statutory constructions, ${ }^{148}$ it continues to be a vital principle in administrative law. Consequently, even if the Lechmere decision continues to define the approach of the Supreme Court to pre-Chevron constructions of statutes, the Clinchfield approach would provide lower courts with a more consistent way of addressing preChevron authority than attempting to predict which pre-Chevron interpretations the Supreme Court will find to have been based on the "clear meaning" of the statute. Considering the lack of evidence supporting Justice Thomas's contention in Lechmere that Babcock had determined the clear meaning of the statutory provision in question, ${ }^{149}$ it is conceivable that any pre-Chevron construction of a statute could be found by the Supreme Court to have been based on that statute's "clear meaning."150 By requiring itself to find clear congressional intent behind an earlier precedent before striking down a new interpretation made by an administrative agency, or to find conclusively that no congressional intent can be found to support an earlier judicial construction, a circuit court would assemble strong arguments for its ruling, should the case go to the Supreme Court. It would also base the decision on the commands of Chevron and thereby require that any attempt to overrule its decision explicitly respond to Cheuron arguments. If this approach were consistently followed in the circuits, it would encourage the Supreme Court to take the values inherent in the Cheuron principle into account when considering earlier constructions of statutes administered by agencies. ${ }^{151}$

148 "In short, the post-Chevron decisions explicating the meaning of Cheuron reveal much that calls into question the Court's fidelity to the doctrine. ... [The] decisions reveal a pattern of qualifying or compromising the doctrine with other principles suggesting that Cheuron rests at best uneasily in the larger body of administrative law." Merrill, 101 Yale L $J$ at 990 (cited in note 9 ).

149 See text accompanying notes 103-08.

${ }^{160}$ See text accompanying notes 109-13.

131 Equally viable responses, of course, would be to expressly limit Chevron in its application to pre-Cheuron precedent, or to overrule Cheuron. Although the first alternative might be attractive to the Court, it would open a logical hole in the doctrine. As Professor Merrill notes: "Indeed, the D.C. Circuit in Chevron had invalidated the EPA's interpretation of 'stationary source' largely because it was contrary to prior D.C. Circuit precedent, and the Court held that this did not justify a departure from deference." Merrill, 101 Yale L $J$ at 989 (cited in note 9). The second alternative, overruling Cheuron, would probably not be attractive to the Court. 


\section{CoNCLUSION}

There is no agreement about what approach to take in considering pre-Cheuron interpretations of statutes that have been reinterpreted by administrative agencies. There appears to be a conflict between the doctrine of stare decisis, requiring courts to uphold earlier judicial constructions of statutes, and the demands of Chevron, which calls for deference to interpretations made by administrative agencies, unless Congress has clearly intended that a particular interpretation should govern.

An approach can be developed by considering one reading of the Supreme Court's decision in Maislin Industries, U.S., Inc. $v$ Primary Steel, Inc. ${ }^{152}$ together with the Ninth Circuit's decision in Mesa Verde Construction Co. $v$ Northern California District Council of Laborers. ${ }^{153}$ This approach calls for a judge to read earlier opinions which construed the statute and determine whether the earlier court believed its interpretation implemented Congress's intent. If so, then the earlier construction would satisfy Chevron's first step and would be binding precedent. If not, then the court would consider the earlier interpretation to have been based on deference, proceed to Chevron's second step, and defer to any reasonable interpretation offered by the administrative agency. ${ }^{154}$

This Comment argues that a better approach, supported by a different reading of Maislin and the D.C. Circuit's decision in Clinchfield Coal v Federal Mine Safety and Health Commission, ${ }^{165}$ would regard any pre-Chevron constructions of statutes reinterpreted by the agencies as only informative, rather than as binding precedent. This approach recognizes that Cheuron radically changed the interpretative context, and that pre-Cheuron notions of deference and responsibility for statutory construction make reliance on earlier opinions less useful than the Mesa Verde court suggested. This approach calls for courts to consider anew the Chevron question when confronted by any agency reinterpretation of a statute. In doing so, courts hew more closely to the central principle of Chevron: responsibility and authority for interpretation of agency-administered statutes should reside with the agencies themselves.

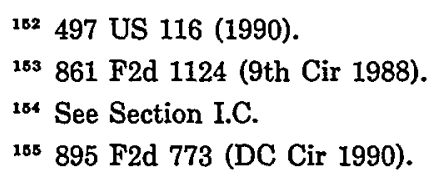

